University of Wollongong

Research Online

Faculty of Engineering and Information

Faculty of Engineering and Information

Sciences - Papers: Part A

Sciences

$1-1-2013$

\title{
Conceptual model describing smear zone caused by mandrel action
}

Cholachat Rujikiatkamjorn

University of Wollongong, cholacha@uow.edu.au

Made Ardana

University of Wollongong, mdwa298@uowmail.edu.au

Buddhima Indraratna

University of Wollongong, indra@uow.edu.au

S Leroueil

Laval University, Quebec

Follow this and additional works at: https://ro.uow.edu.au/eispapers

Part of the Engineering Commons, and the Science and Technology Studies Commons

Research Online is the open access institutional repository for the University of Wollongong. For further information contact the UOW Library: research-pubs@uow.edu.au 


\title{
Conceptual model describing smear zone caused by mandrel action
}

\begin{abstract}
In this study the characteristics and extent of the smear zone are investigated using a large, undisturbed sample. The aim of using such a sample is to capture the realistic characteristics of the smear zone in relation to the in situ soil structure during the installation of prefabricated vertical drains (PVDs) using a mandrel. The extent of the smear zone for Bulli clay (New South Wales, Australia) is determined on the basis of normalised permeability $(\mathrm{k}(\mathrm{h}) / \mathrm{k}(\mathrm{hu})$ ) and the reduction in the water content upon consolidation. The permeability and compressibility of the soil are investigated to determine the extent to which the soil surrounding the PVD has become disturbed. In laboratory testing, the soil consolidation behaviour due to a PVD is studied using a large-scale consolidometer apparatus. The numerical results have shown that the writers' solutions give excellent agreement with laboratory observations.
\end{abstract}

\section{Keywords}

mandrel, conceptual, action, caused, zone, smear, describing, model

Disciplines

Engineering | Science and Technology Studies

\section{Publication Details}

Rujikiatkamjorn, C., Ardana, M., Indraratna, B. \& Leroueil, S. (2013). Conceptual model describing smear zone caused by mandrel action. Geotechnique, 63 (16), 1377-1388. 


\title{
Conceptual model describing smear zone caused by mandrel action
}

\author{
C. RUJIKIATKAMJORN*, M. D. W. ARDANA $\dagger$, B. INDRARATNA* and S. LEROUEIL:
}

In this study the characteristics and extent of the smear zone are investigated using a large, undisturbed sample. The aim of using such a sample is to capture the realistic characteristics of the smear zone in relation to the in situ soil structure during the installation of prefabricated vertical drains (PVDs) using a mandrel. The extent of the smear zone for Bulli clay (New South Wales, Australia) is determined on the basis of normalised permeability $\left(k_{\mathrm{h}} / k_{\mathrm{hu}}\right)$ and the reduction in the water content upon consolidation. The permeability and compressibility of the soil are investigated to determine the extent to which the soil surrounding the PVD has become disturbed. In laboratory testing, the soil consolidation behaviour due to a PVD is studied using a large-scale consolidometer apparatus. The numerical results have shown that the writers' solutions give excellent agreement with laboratory observations.

KEYWORDS: consolidation; structure of soils; laboratory tests; model tests; numerical modelling

\section{INTRODUCTION}

In situ soils usually possess a distinctive structure, whose behaviour is different from that of the same material in a reconstituted state (e.g. Burland, 1990; Leroueil \& Vaughan, 1990; Cuccovillo \& Coop, 1999). There have been numerous studies on developing constitutive models that consider the structure of the soil, such as those proposed by Gens \& Nova (1993), Whittle (1993), Wheeler (1997) and Rouainia \& Muir Wood (2000). In recent years numerous experimental and theoretical studies on the mechanical behaviour of structured clays have been published (Roscoe \& Burland, 1968; Rowe, 1972; Skempton, 1985; Coop et al., 1995; Kavvadas \& Amorosi, 2000). Liu \& Carter (2002) proposed a new constitutive model for structured clays whereby its parameters can be readily determined in the laboratory.

Prefabricated vertical drains (PVDs) have commonly been used to accelerate the consolidation of soft clay. In this process, the PVDs are driven into the clay foundation with a hoist (e.g. on a track-mounted crane) and a steel mandrel that houses the drain and its anchor. The installation of PVDs creates a disturbed region around them (the smear zone) where the structure of the clay is altered such that both the horizontal permeability and the compressibility are decreased. This can prolong the time required for the soil to consolidate. The parameters required to characterise the smear zone are the affected area of the disturbed soil and the ratio of the horizontal coefficient of permeability in the undisturbed zone to that in the smear zone (Chai \& Miura, 1999). Using reconstituted soils, Onoue et al. (1991) investigated the distribution of the horizontal coefficient of permeability through laboratory experiments, and suggested using a three-zone model for any variation in permeability around a drain. In previous studies, the extent of the smear

Manuscript received 18 September 2012; revised manuscript accepted 9 April 2013. Published online ahead of print 16 July 2013.

Discussion on this paper closes on 1 May 2014, for further details see p. ii.

* Centre for Geomechanics and Railway Engineering, School of Civil Engineering, University of Wollongong, Wollongong City, Australia. $\dagger$ Centre for Geomechanics and Railway Engineering, School of Civil Engineering, University of Wollongong, Wollongong City, Australia; and Department of Civil Engineering, Udayana University, Denpasar Bali, Indonesia.

† Department of Civil Engineering, Laval University, Quebec, Canada. zone has been determined, as set out in Table 1. Indraratna \& Redana (1998) estimated the smear zone to be four or five times larger than the equivalent radius of the drain, and the ratio of horizontal to vertical permeability approached unity in the zone. Hird \& Moseley (2000) attempted to determine the characteristics of the smear zone in multilayered soils by measuring the head loss, and then proposed an inner smear zone radius of three times the equivalent radius of the drain. Based on large-scale laboratory tests, Sharma \& Xiao (2000) and Ghandeharioon et al. (2010) concluded that the smear zone is about four times the equivalent radius of the drain and $3 \cdot 1$ times the equivalent radius of the mandrel, determined using elliptical cavity expansion theory respectively. Based on the water content reduction, Sathananthan \& Indraratna (2006) showed that the smear zone radius is 2.5 times the equivalent mandrel radius.

In previous studies, estimation of the smear zone was based mainly on laboratory testing using reconstituted (remoulded) soil, the structure of which was partially or fully destroyed during preparation. In recent years, researchers and practitioners have pointed out the difficulties associated with estimating the smear zone of in situ soil (Chu et al., 2000; Bo et al., 2003). Indraratna \& Redana (2000) introduced a preliminary analytical and numerical model to capture the effect of the smear zone, but the role played by the soil structure was not properly captured. However, as the above findings were based on testing reconstituted soils, none of these approaches correctly captured the role of the soil structure, and therefore the corresponding deformation and excess dissipation of pore pressure associated with soft clays subjected to radial consolidation may not accurately represent the actual behaviour.

Table 1. Extents of the smear zone

\begin{tabular}{l|l}
\hline Authors & Equivalent radius of smear zone, $r_{\mathrm{s}}$ \\
\hline Hansbo (1981) & $1 \cdot 5 r_{\mathrm{m}, \mathrm{eq}}$ (equivalent radius of mandrel) \\
Bergado et al. (1991) & $2 r_{\mathrm{m}, \mathrm{eq}}$ \\
Sathananthan \& Indraratna & $2 \cdot 5 r_{\mathrm{m}, \mathrm{eq}}$ \\
(2006) & $3 \cdot 1 r_{\mathrm{m}, \mathrm{eq}}$ \\
Ghandeharioon et al. (2010) & $4 r_{\mathrm{m}, \mathrm{eq}}$ \\
Sharma \& Xiao (2000) & $4-5 r_{\mathrm{w}}$ (radius of central drain) \\
Indraratna \& Redana (1998) &
\end{tabular}


In the present study, a large, undisturbed sample was obtained to assess the altered soil properties, such as permeability and compressibility, in the smear zone after the installation of PVDs. The aim was to capture more realistic characteristics of the smear zone with the structure of the soil intact. The destructuring of clay during installation was assessed through changes in the void ratio, permeability and compressibility. A consolidation test was conducted on the large sample, and then the smear characteristics were evaluated using small specimens cored at various locations.

\section{COMPRESSION BEHAVIOUR OF RECONSTITUTED AND STRUCTURED SOILS}

The structure of soil can normally be measured using the variation in the void ratio obtained from compression tests. Liu \& Carter (1999) discussed how the behaviour of a structured soil differs from the same soil in a reconstituted condition in at least three ways.

(1) Intact structure represents a material that is initially stiff, or at relatively low stress levels.

(2) Soil with structure sustains a higher void ratio than a corresponding reconstituted soil.

(3) During virgin yielding, a structured soil is generally more compressible than a reconstituted soil, but it moves closer to becoming a reconstituted soil as destructuring progresses.

A material idealisation of the isotropic compression of structured and reconstituted soils during virgin compression is shown in Fig. 1 with the variation of the void ratio due to destructuring during compression (Liu \& Carter, 1999, 2000). The complete expressions for the reconstituted and structured soil curves in Fig. 1 are

$$
\begin{aligned}
& e^{*}=e_{\mathrm{ic}}^{*}-\lambda^{*} \ln p^{\prime} \\
& e=e_{\mathrm{ic}}^{*}+\Delta e_{\mathrm{i}}\left(\frac{p_{\mathrm{y}, \mathrm{i}}^{\prime}}{p_{\mathrm{s}}^{\prime}}\right)^{b}-\lambda^{*} \ln p^{\prime} \text { for } p_{\mathrm{s}}^{\prime} \geqslant p_{\mathrm{y}, \mathrm{i}}^{\prime}
\end{aligned}
$$

where $e^{*}$ is the void ratio of reconstituted soil during isotropic compression; $e_{\mathrm{ic}}^{*}$ is the void ratio of reconstituted soil when $p^{\prime}=1 \mathrm{kPa}$ during virgin isotropic compression; $\lambda^{*}$ is the gradient of the isotropic compression line (ICL) of the reconstituted soil; $e$ is the void ratio of undisturbed (structured) soil; $\Delta e_{\mathrm{i}}$ is the difference in void ratio between structured and reconstituted soil at the initial yield point; $p_{\mathrm{y}, \mathrm{i}}^{\prime}$ is the value of the mean effective stress at the initial yield point; $p_{\mathrm{s}}^{\prime}$ is the value of the current structural yield surface of partially disturbed soil; $p^{\prime}$ is the current mean effective stress; and $b$ is a parameter representing the rate of destructuring.

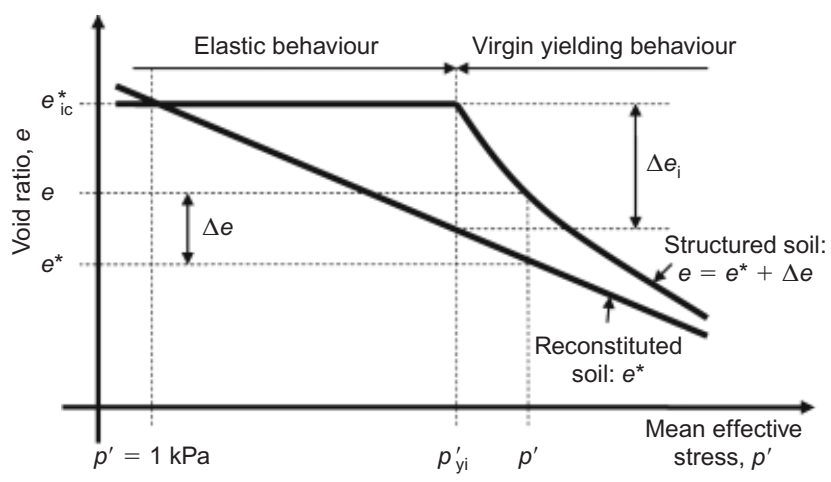

Fig. 1. Idealisation of compression of reconstituted and structured soils (after Liu \& Carter, 2002)
The destructuration of clay was also explained by Leroueil et al. (1979). A pair of consolidation tests were performed on intact and destructured samples of Saint Alban clay to study the variation of volumetric deformation with mean effective stress. The results showed that the path from a natural state (structurally intact) to a destructured state when the clay is loaded beyond its preconsolidation pressure causes significant changes in the behaviour of the soil. It was also mentioned that modifications to the behaviour of the soil included the shape and position of its limit state curve, the values of shear and compression moduli in the overconsolidated states, the mode of pore pressure generation, and the associated peak and large-strain shear strengths.

\section{LARGE-SCALE CONSOLIDOMETER}

A schematic diagram of the modified large-scale consolidometer is given in Fig. 2, following the original design by Indraratna \& Redana (1998). The consolidometer consists of three main parts: (a) the cylinder, which can be used as a corer to obtain an undisturbed sample, and serves as a rigid boundary during consolidation; (b) the loading rig platform; and (c) the pneumatic air pressure chamber. The cylindrical tube (corer) was made from $5 \mathrm{~mm}$ thick steel plate rolled to form two half cylinders, each $700 \mathrm{~mm}$ long and with $345 \mathrm{~mm}$ internal diameter. The height of sample is $561 \mathrm{~mm}$. The space between the top of the sample and the top of the corer is taken to accommodate the top cap. To minimise sample disturbance during the retrieval stage, the dimensions of the corer were designed on recommendations by Hvorslev (1949), which involve the parameters of the area ratio $\left(C_{\mathrm{a}}\right)$, the outside clearance ratio $\left(C_{0}\right)$, and the inside clearance ratio $\left(C_{\mathrm{i}}\right)$. These ratios were defined as follows.

$$
\begin{aligned}
C_{\mathrm{a}} & =\frac{D_{\mathrm{w}}^{2}-D_{\mathrm{e}}^{2}}{D_{\mathrm{e}}^{2}} \\
C_{\mathrm{i}} & =\frac{D_{\mathrm{s}}-D_{\mathrm{e}}}{D_{\mathrm{e}}} \\
C_{\mathrm{o}} & =\frac{D_{\mathrm{w}}-D_{\mathrm{t}}}{D_{\mathrm{t}}}
\end{aligned}
$$

where $D_{\mathrm{w}}$ is the outside diameter of the tube that enters the soil during sampling; $D_{\mathrm{e}}$ is the inside diameter of the cutting edge of the sampling device; $D_{\mathrm{t}}$ is the outside diameter of the sampling tube; and $D_{\mathrm{s}}$ is the inside diameter of the sampling tube above the cutting edge.

Disturbance in the soil sample increases with increasing area ratio, and therefore the area ratio should be within $10 \%$. It is suggested that the inside clearance ratio for the short samplers should be between 0 and $1.5 \%$. The outside clearance ratio for cohesive soil should not exceed 2-3\% (Hvorslev, 1949). Hight \& Leroueil (2003) provide the criteria for good-quality sampling of soft clays: (a) no inside clearance; (b) thin wall, and $C_{\mathrm{a}}$ as small as possible; (c) small cutting edge angle (5-6 $6^{\circ}$ for the best samplers); and (d) large diameter of sampler. The proposed corer in the current study has met the suggested criteria, with an area ratio of $5.88 \%$. There is no clearance inside or outside the corer.

The sleeves on both ends of the half cylinder corer were specially designed so that they formed a perfect cylinder. A Teflon film was sprayed all over the surface of the inner wall to reduce friction between the soil and the wall during coring and consolidation. The cylinder can be fitted with top and bottom caps; the top cap was made from $6 \mathrm{~mm}$ thick steel plate, and was designed to be stiff enough during retrieving to ensure that the sample remained undisturbed. 


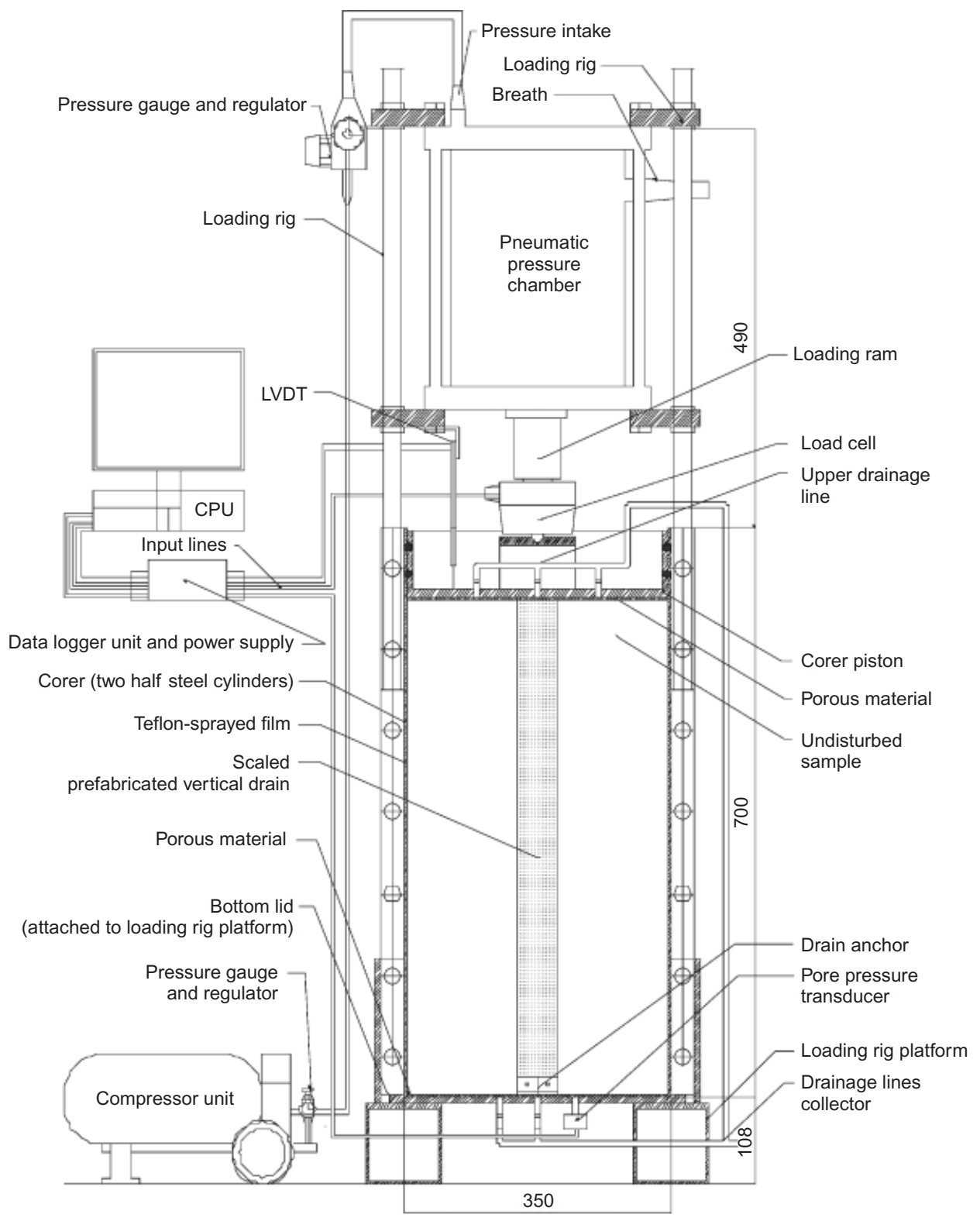

Fig. 2. Large-scale consolidometer (units $\mathbf{m m}$ )

Both caps have three drainage valves that can be opened or closed during sampling and testing. As there was no backpressure applied in the consolidation chamber, the saturation of sample need to be verified using Skempton's $B$ value. A stainless steel piston, $342 \mathrm{~mm}$ in diameter, was placed on top of the sample to ensure that the load from the pneumatic air pressure chamber was distributed uniformly, and to ensure uniform vertical deformation during consolidation. To prevent water from leaking past the piston, there are two grooves around its periphery for two $5 \mathrm{~mm}$ diameter O-rings. To ensure negligible side friction, Teflon spray was applied at the interface between the O-rings and the inner wall.

\section{RECOVERY OF UNDISTURBED SAMPLE}

The samples of undisturbed lacustrine soil used in this experiment were obtained from a site at Bulli, New South Wales, Australia. The physical properties of the soil are given in Table 2. Based on the Unified Soil Classification System, the soil was classified as an inorganic clay with high plasticity $(\mathrm{CH})$. These samples were retrieved from the site using a light excavator, which pushed the corer into the
Table 2. Soil properties of Bulli clay

\begin{tabular}{l|c}
\hline Property & Values \\
\hline Liquid limit: \% & 50 \\
Plastic limit: \% & 25 \\
Plasticity index & 25 \\
Specific gravity & $2 \cdot 62$ \\
Water content: $\%^{*}$ & $41 \cdot 4$ \\
Void ratio, $^{*}$ & $1 \cdot 13$ \\
Wet unit weight: $^{*} \mathrm{kN} / \mathrm{m}^{3}$ & $18 \cdot 5$ \\
\hline
\end{tabular}

* Obtained from small-size, undisturbed sample.

cleared surface at the required depth. The top cap was attached to the corer to prevent the sample from moving, and from losing moisture. The reason for pushing the corer with a steady force was to maintain a continuous and uniform motion, and thus minimise the degree of disturbance. The static push method described above prevents any rotation, and is a recommended and longstanding technique for obtaining quality samples (Hvorslev, 1949). In this study 
the sampling depth was approximately $2 \mathrm{~m}$ from the surface, where the preconsolidation pressure was approximately $80 \mathrm{kPa}$, with an overconsolidation ratio of $2 \cdot 5$. Subsequently, the soil surrounding the corer was excavated, and a sample was cut from the bottom of the pit. The samples were sealed at the base to prevent any loss of moisture. The top and end caps were placed on the top and bottom of the sample to ensure that there was no air gap at the interfaces between the soil and the caps, and to prevent any further stress relief. The samples were kept in a humidity-controlled room before testing.

\section{TESTING PROGRAMME Consolidation}

The lower part of the cylindrical sample was docked on the bottom platform, and the upper part was attached to a specially designed loading rig. A load cell was placed between the piston and the pneumatic air pressure chamber, and an axial displacement transducer was installed on top of the piston to measure the vertical settlement. The applied load and settlements were recorded using a data logger. A hollow rectangular mandrel made from $1.5 \mathrm{~mm}$ thick stainless steel plate was used to install a scaled-down, bandshaped drain. The mandrel was $5 \mathrm{~mm}$ thick and $55 \mathrm{~mm}$ wide, which provided an equivalent mandrel radius $\left(r_{\mathrm{m}, \mathrm{eq}}\right)$ of $16 \cdot 2 \mathrm{~mm}$. A rectangular drain anchor with the same crosssection as the mandrel was also attached to the drain prior to installation. The single, band-shaped (rectangular crosssection) PVD consisted of a non-woven synthetic geotextile material surrounding a plastic core. For the purpose of laboratory simulation, the width of the drain was scaled down from $100 \mathrm{~mm}$ to $50 \mathrm{~mm}\left(r_{\mathrm{W}}=13.5 \mathrm{~mm}\right)$, given the size of the sample diameter of $350 \mathrm{~mm}$. Installation of the drain was completed by manually pushing the mandrel vertically into the sample at a constant speed, and then withdrawing it immediately after it reached the base. A mandrel guide was also used to ensure that the PVD was installed along the centreline of the specimen.

\section{Experimental arrangement and test procedure}

Two experimental series, $\mathrm{A}$ and $\mathrm{B}$, were subjected to maximum applied pressures of $50 \mathrm{kPa}$ and $200 \mathrm{kPa}$ respectively. Both series were subjected to a vertical pressure of $20 \mathrm{kPa}$, which represented the in situ vertical effective stress. The sample was expected to be in a saturated state in situ, as it was retrieved from a location below the water table. After placing it in the one-dimensional oedometer cell with an applied consolidation pressure of $20 \mathrm{kPa}$, full saturation was verified by Skempton's $B$ value approaching 0.99. As there was no back-pressure applied in the consolidation chamber, the applied consolidation pressure was indeed effective stress. With Series A, an additional total vertical stress of $30 \mathrm{kPa}$ was applied, and with Series B, three loading stages were applied in order to achieve total pressures of $50 \mathrm{kPa}$, $100 \mathrm{kPa}$ and $200 \mathrm{kPa}$. The test was carried out in three phases: (a) preparation of the sample and loading rig; (b) installation of the PVD, and the consolidation test; (c) small sample (specimen) coring for the moisture content and oedometer tests. In the first phase, the large-scale undisturbed sample was assembled on the loading rig platform. The drainage valves on the piston and base were both opened to collect any excess water. In this phase a vertical consolidation pressure of $20 \mathrm{kPa}$ was applied to simulate the in situ effective stress.

In the consolidation phase, after the application of preconsolidation pressure, the piston was removed from the sample. A mandrel guide was bolted onto the top of the sample to ensure that the mandrel was installed vertically, the drain was pushed into the sample, and the piston was placed on top of the sample. The vertical consolidation pressure was applied to the sample in accordance with the test series, until the primary consolidation process was complete. The vertical displacement curves that occurred during the application of consolidation pressure for both samples are plotted in Fig. 3. For Series B, the vertical displacement under a vertical total stress of $20 \mathrm{kPa}$ is $4 \mathrm{~mm}$, corresponding to a vertical strain of about $0.7 \%$. This points to some sample disturbance effect. Since additional loading up to $50 \mathrm{kPa}$ had produced similar displacements, this sample disturbance, although limited, might have had a significant effect on the results obtained for Series A, which ended at $50 \mathrm{kPa}$.

After the primary consolidation process had been completed, the cell was split into two parts to enable specimens to be collected from various locations. The horizontal and vertical specimens obtained from two layers at a particular depth are shown in Fig. 4(a). The specimen prepared for the oedometer test was $50 \mathrm{~mm}$ in diameter and $20 \mathrm{~mm}$ thick. The oedometer tests were conducted to obtain the compressibility and permeability of the clay specimens by way of time-settlement curves. Five undisturbed specimens were obtained from each layer, at a given distance from the centre of the drain, for the D-axis and A-axis, as shown in Fig. 4(b). The D-axis samples were collected along the width of the drain, and the A-axis samples were collected along the thickness of the drain. The three layers selected for sampling were $450 \mathrm{~mm}, 350 \mathrm{~mm}$ and $250 \mathrm{~mm}$ from the base. The small horizontal and vertical samples $(4 \mathrm{H}, 3 \mathrm{H}, 2 \mathrm{H}, 1 \mathrm{H}$ and $0 \mathrm{H})$ were collected at $140 \mathrm{~mm}, 90 \mathrm{~mm}, 60 \mathrm{~mm}, 30 \mathrm{~mm}$ and $0 \mathrm{~mm}$ radial distances from the centre of the drain. The compressibility of the clay of the undisturbed and remoulded samples was determined based on the vertical samples, whereas the permeability was determined based on the horizontal samples.

\section{TEST RESULTS AND ANALYSIS}

Characterisation of smear zone based on moisture content, void ratio and permeability

The variations in moisture content at radial distances for the Series B samples are shown in Fig. 5. The variations of water content at different depths can be attributed to the in situ condition whereby the corresponding in situ moisture content also increases with depth in a similar trend. At the same time, moisture content tests were conducted at the same locations. The variations in moisture content for the D-axis

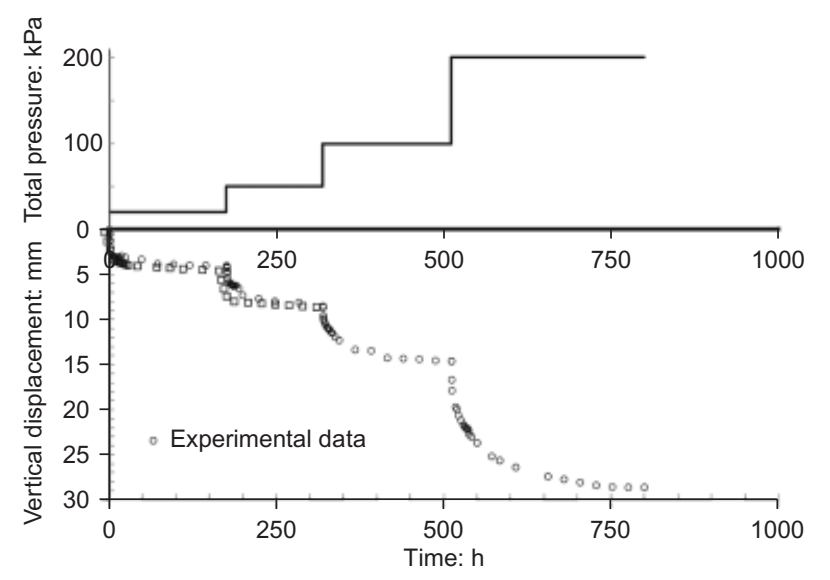

Fig. 3. Vertical displacement against time for large samples (Series A, squares; Series B, circles) 


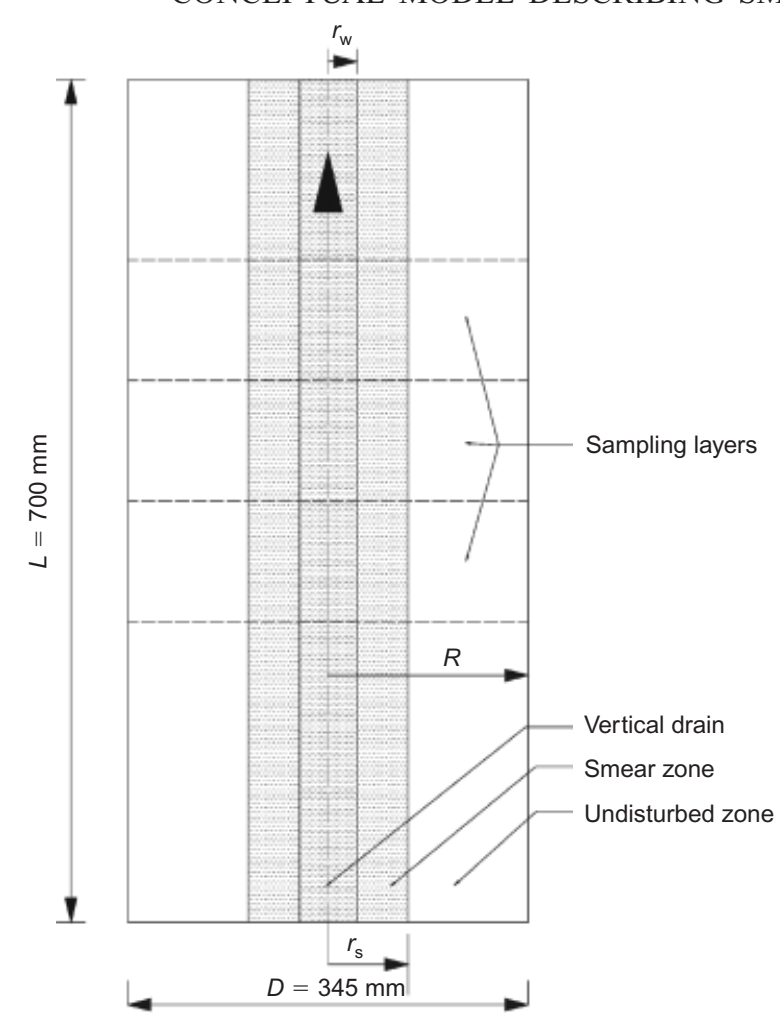

(a)

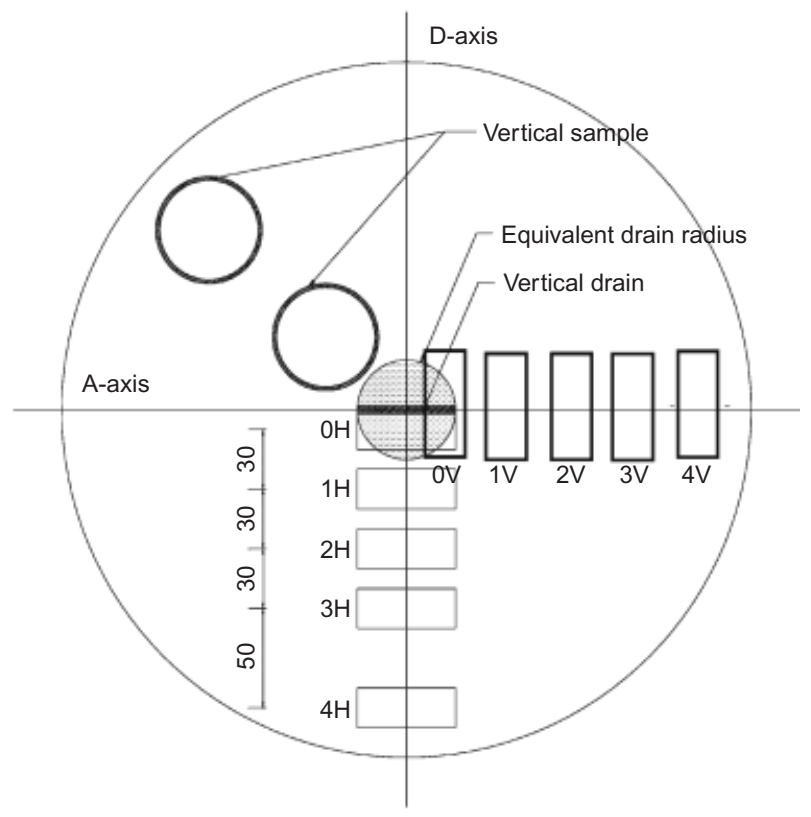

(b)

Fig. 4. (a) Unit cell, showing the sampling layers; (b) schematic cross-section of small sampling locations for oedometer test

and A-axis samples have probably been influenced by the installation of the drain within a radius of $60-90 \mathrm{~mm}$ from the centre. Based on the observed data, the radius of the smear zone can be estimated to be $60 \mathrm{~mm}$ in relation to the specific positions of the small oedometer specimens. Fig. 6 shows the variation of the void ratio from horizontal specimens collected from both large-scale samples. The distribution of the void ratio in a radial direction shows that the void ratio reduced further in the region adjacent to the drain $(0-60 \mathrm{~mm})$. There was a significant drop in the void ratios in this region, which was approximately 3.7 times the equivalent mandrel radius $\left(r_{\mathrm{m}}\right)$, so this region could be considered representative of the

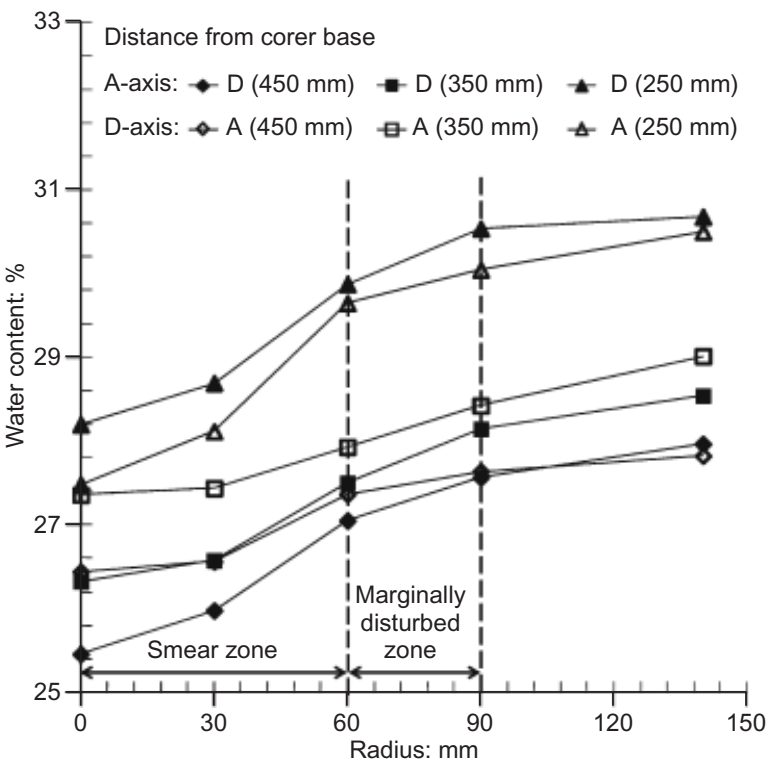

Fig. 5. Moisture content of Series B samples

smear zone. Outside this zone, the void ratios tended to have a relatively constant value at a distance of more than $60 \mathrm{~mm}$ towards the boundary of the sample.

Figure 6 also shows the variation of horizontal permeability in the radial direction. The permeability curves show a similar trend to the void ratio and moisture content, where permeability close to the drain was lower in those samples further away from the drain. Permeability beyond a radius of $60 \mathrm{~mm}$ shows a relatively constant value. The estimated extent of smear based on the variations in permeability agrees well with those based on both the moisture content and void ratio. In the area beyond $90 \mathrm{~mm}$ from the centre, soil disturbance was found to be minimal. It was clear that there were two disturbed zones surrounding the drain, which were either completely disturbed or marginally disturbed. Onoue et al. (1991) and Madhav et al. (1993) also divided the smear zone into two subzones: an inner zone with highly disturbed soil, and an outer transition zone where the disturbance gradually decreased as the distance from the centre of the drain increased.

Figure 6 also presents the change of normalised horizontal permeability $\left(k_{\mathrm{h}} / k_{\mathrm{hu}}\right)$ along the radial distance for both largescale samples with maximum consolidation pressures of $50 \mathrm{kPa}$ and $200 \mathrm{kPa}$. The normalised horizontal permeability is the ratio of the horizontal permeability of partially undisturbed soil $\left(k_{\mathrm{h}}\right)$ to the horizontal permeability of undisturbed soil $\left(k_{\mathrm{hu}}\right)$. The horizontal permeability of the largescale sample in the region that is $60 \mathrm{~mm}$ from the centre is approximately $50-80 \%$, which is an average of $65 \%$ lower than in the undisturbed zone. It can be seen that the reduction in permeability obtained from this study using undisturbed samples was significantly larger than those using remoulded soil in past studies by Indraratna \& Redana (1998) and Sharma \& Xiao (2000). The larger reduction in permeability in the disturbed zone was almost twice that in the remoulded sample.

Determination of soil disturbance due to drain installation

Soil destructuration can occur when samples are being retrieved, or drains are being installed by the steel mandrel. The degree of disturbance can be quantified using the compression curves (Schmertmann, 1955; Nagaraj et al., 1990; Nagendra Prasad et al., 2007). Most specimens with some degree of disturbance will show a compression curve that 


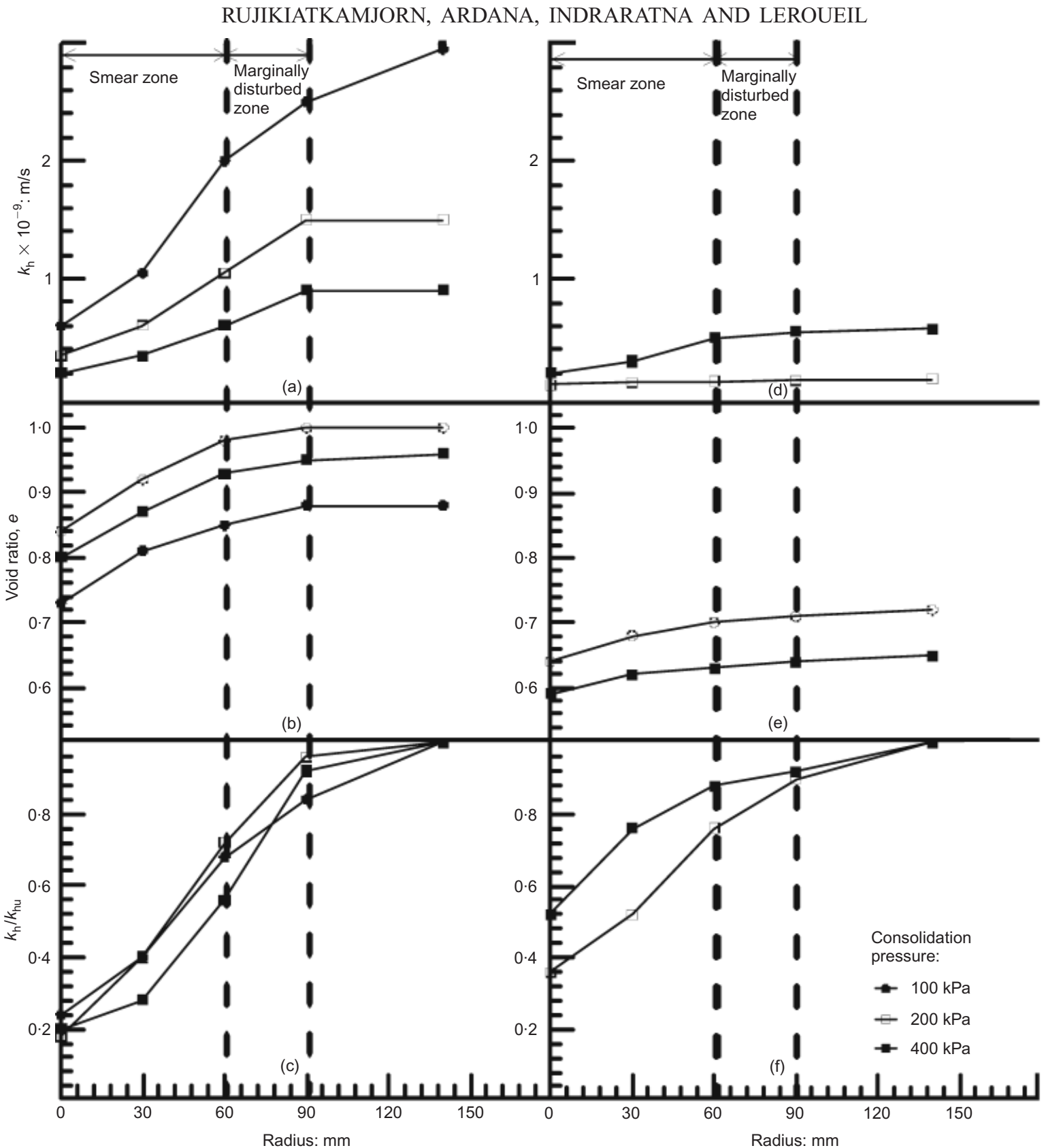

Fig. 6. Series A: (a) radial distribution of horizontal permeability; (b) void ratio; (c) normalised permeability. Series B: (d) radial distribution of horizontal permeability; (e) void ratio; (f) normalised permeability

falls in between the compression curves of the undisturbed and completely remoulded samples (Rutledge, 1944). Therefore a structured soil represents an ideal condition for insignificant disturbance, whereas a reconstituted soil represents a disturbed soil, or the condition of destructuration. In view of the above, a conceptual model to evaluate the degree of disturbance in relation to the soil structure is proposed, using the compression curves shown in Fig. 7 and the conceptual description given below.

\section{Characteristics of the conceptual model}

(a) The compression curves of partially disturbed soil can be obtained by plotting the void ratio against the mean effective stress on a semi-log scale. It is assumed that the yield stress of the partially disturbed soil is located on the extrapolation of the line $\mathrm{AB}$ (Fig. 7) through the yield stress points intersecting the horizontal line from the in situ void ratio. This line is perpendicular to the intrinsic state line (Nagaraj et al., 1990).

(b) Based on the concept of a structured Cam Clay model (Liu \& Carter, 2000), in the elastic behaviour region the void ratios of the reconstituted soil, $e^{*}$, and the structured soil (undisturbed soil), $e_{\mathrm{sc}}$, are given by the following equations. The laboratory testing in this study was carried out under one-dimensional conditions, and the original parameters $\lambda, \kappa$, and $p^{\prime}$ were replaced by $C_{\mathrm{c}}, C_{\mathrm{s}}$ and $\sigma_{\mathrm{v}}^{\prime}$ respectively.

$$
\begin{aligned}
& e^{*}=e_{\mathrm{ic}}^{*}-C_{\mathrm{c}} \log \sigma_{\mathrm{v}}^{\prime} \\
& e_{\mathrm{sc}}=e_{\mathrm{ic}}^{*}-C_{\mathrm{s}} \log \sigma_{\mathrm{v}}^{\prime} \text { for } 1 \leqslant \sigma_{\mathrm{v}}^{\prime} \leqslant \sigma_{\mathrm{vy}, \mathrm{i}}^{\prime}
\end{aligned}
$$

Equations (6) and (7) are for the reconstituted soil and the undisturbed soil respectively. 


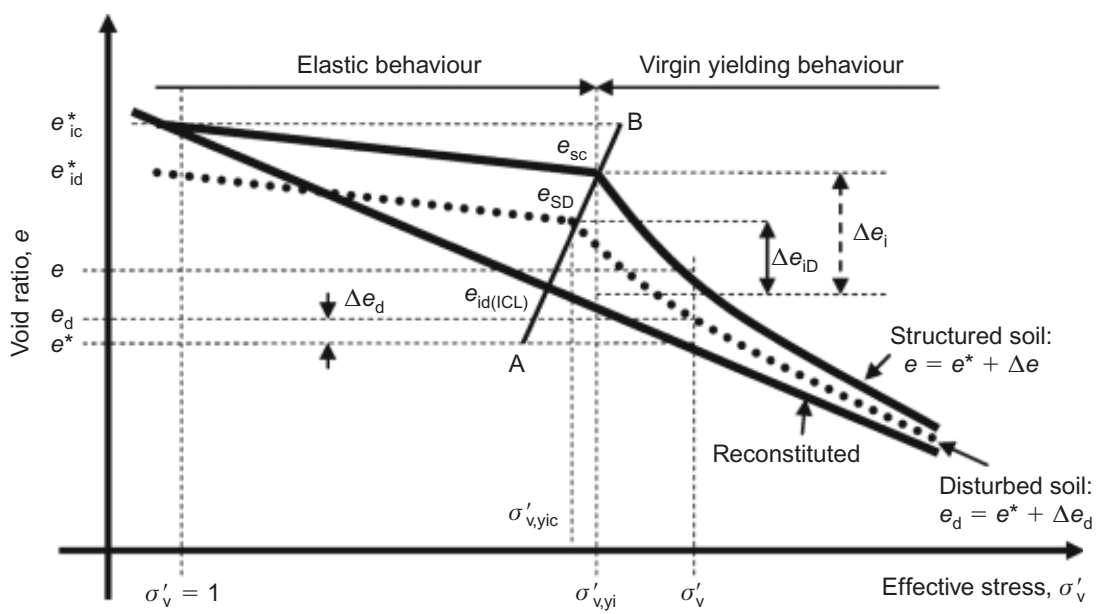

Fig. 7. Proposed concept to evaluate the degree of soil disturbance

(c) For the virgin yielding behaviour, the void ratio $(e)$ of the structured (undisturbed) soil is given by

$$
\begin{aligned}
& e=e_{\mathrm{ic}}^{*}+\Delta e_{\mathrm{i}}\left(\frac{\sigma_{\mathrm{vy}, \mathrm{i}}^{\prime}}{\sigma_{\mathrm{vs}}^{\prime}}\right)^{b}-C_{\mathrm{c}} \log \sigma_{\mathrm{v}}^{\prime} \text { for } \sigma_{\mathrm{v}}^{\prime} \geqslant \sigma_{\mathrm{vy}, \mathrm{i}}^{\prime} \\
& \Delta e_{\mathrm{i}}=e_{\mathrm{sc}}-e_{\mathrm{id}(\mathrm{ICL})}
\end{aligned}
$$

where $e_{\mathrm{id}(\mathrm{ICL})}$ is the void ratio on the ICL at an effective stress of $\sigma_{\mathrm{vy}, \mathrm{i}}^{\prime}$ in the structured soil.

(d) The line AB can be constructed to obtain the loci of yield stress for the partially disturbed soil. The proposed line on which the yield envelopes lie is the line through point $\mathrm{B}$ of the value of the initial yield stress $\left(\sigma_{\mathrm{vy}, \mathrm{i}}^{\prime}\right)$ of the structured soil and the perpendicular intersect of the ICL of the reconstituted soil at point A. The initial yield stress of the partially disturbed soil $\left(\sigma_{\mathrm{vy}, \mathrm{iD}}^{\prime}\right)$ and its respective void ratio are expected to be located on this line. Then the point $\mathrm{A}\left(\sigma_{\mathrm{vy}, \mathrm{iD}}^{\prime}, e_{\mathrm{P}}\right)$ can be readily calculated using the equations

$$
\begin{aligned}
& \sigma_{\mathrm{vy}, \mathrm{iD}}^{\prime}=10\left[C_{\mathrm{c}}\left(e_{\mathrm{iD}(\mathrm{ICL})}-e_{\mathrm{ic}}^{*}\right)+\log \sigma_{\mathrm{vy}, \mathrm{i}}^{\prime}\right] \\
& e_{\mathrm{P}}=\frac{\log \sigma_{\mathrm{vy}, \mathrm{iD}}^{\prime}-\log \sigma_{\mathrm{vy}, \mathrm{i}}^{\prime}}{C_{\mathrm{c}}}+e_{\mathrm{ic}}^{*}
\end{aligned}
$$

where $e_{\mathrm{id}}$ is the initial void ratio of the partially disturbed soil; $\sigma_{\mathrm{vy}, \mathrm{iD}}^{\prime}$ is the yield stress of the partially disturbed soil; and $e_{\mathrm{P}}$ is the void ratio of the partially disturbed soil at the yield points line (line $A B$ ).

(e) The void ratio of the partially disturbed soil, $e_{\mathrm{SD}}$, in the elastic behaviour region is given by

$$
e_{\mathrm{SD}}=e_{\mathrm{id}}-C_{\mathrm{S}} \log \sigma_{\mathrm{v}}^{\prime} \text { for } 1 \leqslant \sigma_{\mathrm{v}}^{\prime} \leqslant \sigma_{\mathrm{vy}, \mathrm{iD}}^{\prime}
$$

The void ratio $\left(e_{\mathrm{D}}\right)$ in the virgin yielding behaviour region can then be calculated as

$$
e_{\mathrm{D}}=e_{\mathrm{id}}+\Delta e_{\mathrm{iD}}\left(\frac{\sigma_{\mathrm{vy}, \mathrm{iD}}^{\prime}}{\sigma_{\mathrm{vs}}^{\prime}}\right)^{b}-C_{\mathrm{c}} \log \sigma_{\mathrm{v}}^{\prime} \text { for } \sigma_{\mathrm{vs}}^{\prime} \geqslant \sigma_{\mathrm{vy}, \mathrm{iD}}^{\prime}
$$

$$
\Delta e_{\mathrm{iD}}=e_{\mathrm{SD}}-e_{\mathrm{id}(\mathrm{ICL})}
$$

Based on the change of void ratio of the partially disturbed soil at each respective point of the maximum yield stress along the yield points line $\mathrm{AB}$, the defined degree of disturbance (DD) due to soil destructuration can be quantified as

$$
\mathrm{DD}=1-\left(\frac{e_{\mathrm{SD}}-e_{\mathrm{id}(\mathrm{ICL})}}{e_{\mathrm{sc}}-e_{\mathrm{id}(\mathrm{ICL})}}\right)
$$

A small sample of undisturbed clay and a remoulded sample were tested using the conventional oedometer apparatus to set up the boundaries of the virgin undisturbed curve and the remoulded curve. The specimens cored along the radial distance from the centre of the drain, considered to be partially disturbed, were also tested with the oedometer apparatus. Fig. 8 shows the plots of void ratio against the effective stress of the various partially disturbed soils obtained from the tests corresponding to Series A and Series B. The experimental results shown in Fig. 8 follow only roughly the conceptual scheme of Fig. 7. The hypothesis that the yield points move along the normal to the reconstituted compression line cannot be accurately captured, given the paucity of the oedometer experimental points. The values of the model parameters obtained from oedometer tests for Series A and Series B are presented in Table 3. It can be seen that the soil became increasingly disturbed towards the drain as the soil adjacent to the drain experienced considerable remoulding due to drain installation. The plots of the experimental data and the model predictions are in good agreement.

In relation to the curves plotted in Fig. 8, an attempt to quantify the degree of disturbance to the soil is now presented. It is noted that $C_{\mathrm{s}}$ of the partially disturbed soil is larger than that of the undisturbed soil (Fig. 8(a)). This aspect was ignored in the model by Liu \& Carter (2002). Fig. 9(a) shows the degree of disturbance of soil structures against the radial distances after the drain was installed and the soil was loaded. The degree of disturbance of the partially disturbed soil is calculated using equation (15), and, as expected, the surrounding soil adjacent to the drain shows a higher degree of disturbance. Based on the model predictions for the relatively undisturbed region, the degree of disturbance can still be approximately $19 \%$ and $22 \%$ for the Series A and Series B samples respectively. Disturbance could also occur as a result of coring smaller specimens from the large samples. In the disturbed (smear) region, the degree of disturbance was approximately $32 \%$ under a consolidation pressure of $50 \mathrm{kPa}$. For the Series B samples subjected to a higher consolidation pressure of $200 \mathrm{kPa}$, the degree of disturbance in the disturbed zone was approximately $45 \%$, whereas that in the undisturbed zone was $25 \%$. 


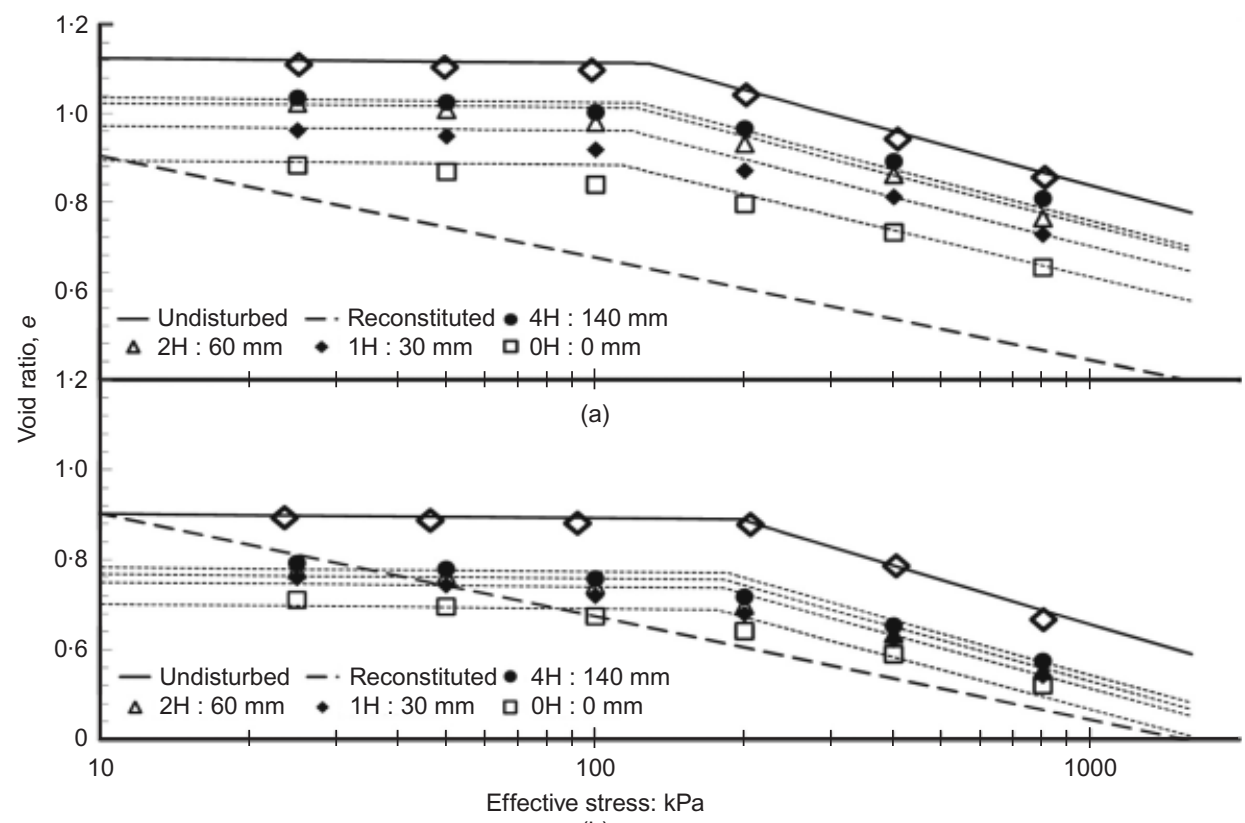

(b)

Fig. 8. Void ratio of partially disturbed soils

Table 3. Model parameters

\begin{tabular}{|c|c|c|c|c|c|c|}
\hline Parameter & $e_{\mathrm{ic}}^{*}$ & $C_{\mathrm{c}}$ & $C_{\mathrm{c}}$ & $C_{\mathrm{s}}$ & $b$ & $\sigma_{\mathrm{yi}}^{\prime}: \mathrm{kPa}$ \\
\hline A-Series & $1 \cdot 134$ & $0 \cdot 23$ & $0 \cdot 23$ & 0.01 & 0.08 & 130 \\
\hline B-Series & $1 \cdot 134$ & $0 \cdot 23$ & $0 \cdot 24$ & $0 \cdot 01$ & 0.08 & 200 \\
\hline$e_{\mathrm{id}}^{*}$ & \multicolumn{3}{|c|}{ Series A } & \multicolumn{3}{|c|}{ Series B } \\
\hline $0 \mathrm{H}$ & \multicolumn{3}{|c|}{0.903} & \multicolumn{3}{|c|}{0.711} \\
\hline $1 \mathrm{H}$ & \multicolumn{3}{|c|}{0.980} & \multicolumn{3}{|c|}{0.759} \\
\hline $2 \mathrm{H}$ & \multirow{2}{*}{\multicolumn{3}{|c|}{$\begin{array}{l}1.032 \\
1.044\end{array}$}} & \multicolumn{3}{|c|}{0.777} \\
\hline $4 \mathrm{H}$ & & & & \multicolumn{3}{|c|}{0.793} \\
\hline
\end{tabular}

\section{Effects of disturbance on consolidation}

As shown in Figs 6, 9(a), 9(b) and 10, the relationships between the horizontal permeability $\left(k_{\mathrm{h}}\right)$ and the horizontal coefficient of consolidation $\left(C_{\mathrm{h}}\right)$ were graphically illustrated as a function of the radial distance from the centre of the drain for various consolidation pressures. The values of $C_{\mathrm{h}}$ were determined using Taylor's square root of time method. Fig. 9 shows that there is a gradual reduction of $C_{\mathrm{h}}$ towards the centre of the drain, and that $C_{\mathrm{h}}$ for all applied pressures approaches an average of $1.5 \times 10^{-7} \mathrm{~m}^{2} / \mathrm{s}$ in the region adjacent to the drain interface. It is clear that, when the soil is disturbed, the permeability and coefficient of consolidation decrease (Fig. 10).

\section{Numerical modelling of vertical drain}

A finite-element program (PLAXIS 2D) is employed to simulate the unit cell of a vertical drain. The consolidation analysis, based on Biot's solution, was used in conjunction with the soft soil model (Brinkgreve et al., 2011). This analysis employed 15-node triangular elements consisting of 15 nodes and 12 integration (stress) points, as shown in Fig. 11(a). The soil unit cell in the finite-element analysis considers only one half of the cell, owing to the axisymmetric model selection, as shown in Figs 11(b), 11(c) and 11(d).
The top, bottom and outer boundaries are set as impermeable. The geometry fixities of the unit cell model allow vertical displacement, but constrain displacement in the horizontal direction. In order to generate uniform settlement (equal strain condition), rigid elements were selected at the soil surface. A series of vertical uniform loads is selected to simulate the load applied during consolidation. The drain is positioned at a distance equal to the drain radius $\left(r_{\mathrm{w}}=13.5 \mathrm{~mm}\right)$ from the unit cell centreline. The unit cell is $345 \mathrm{~mm}$ in diameter and $561 \mathrm{~mm}$ high. Three cases are examined, as follows.

(a) Case A (three-zone simulation). The unit cell consists of three zones that represent the smear zone, marginally disturbed zone and undisturbed zone, where the soil permeability and compressibility vary according to the degree of disturbance observed in the laboratory. The relevant soil properties are shown in first part of Table 4 . The smear zone radius $\left(r_{\mathrm{s}}\right)$ and marginally disturbed zone $\left(r_{\mathrm{md}}\right)$ are $60 \mathrm{~mm}$ and $90 \mathrm{~mm}$ respectively, based on laboratory testing. The ratios of horizontal soil permeability in the undisturbed zone $\left(k_{\mathrm{h}}\right)$ to that in the marginally disturbed zone and that in the smear zone are approximately 1.4 and 3.2 respectively.

(b) Case B (two-zone simulation). The unit cell consists of 


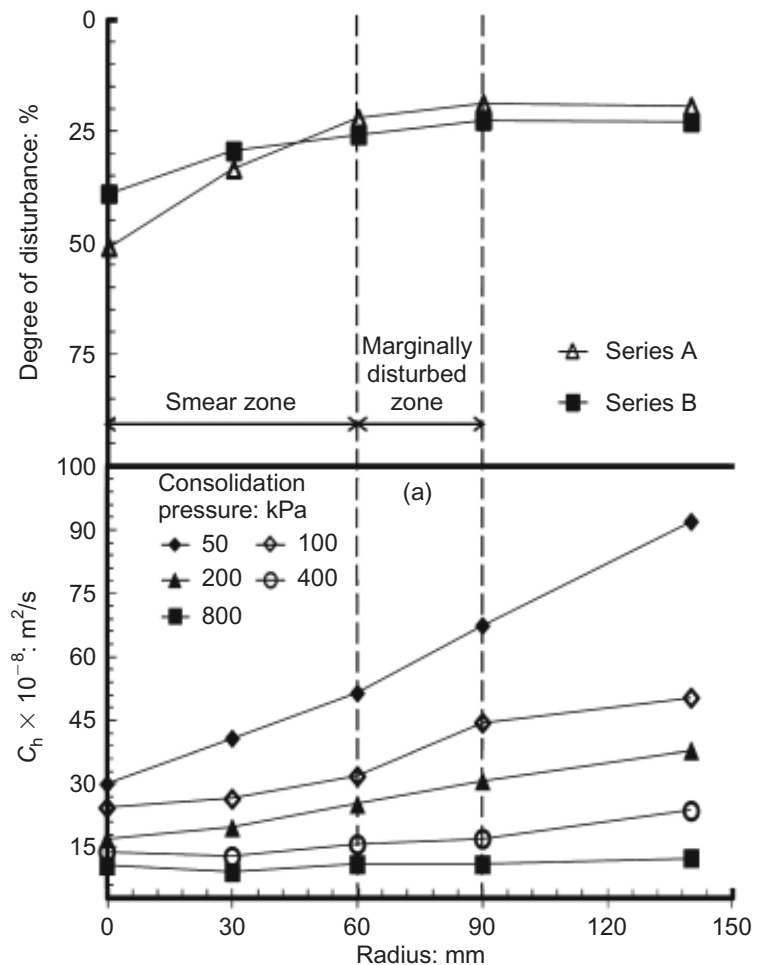

(b)

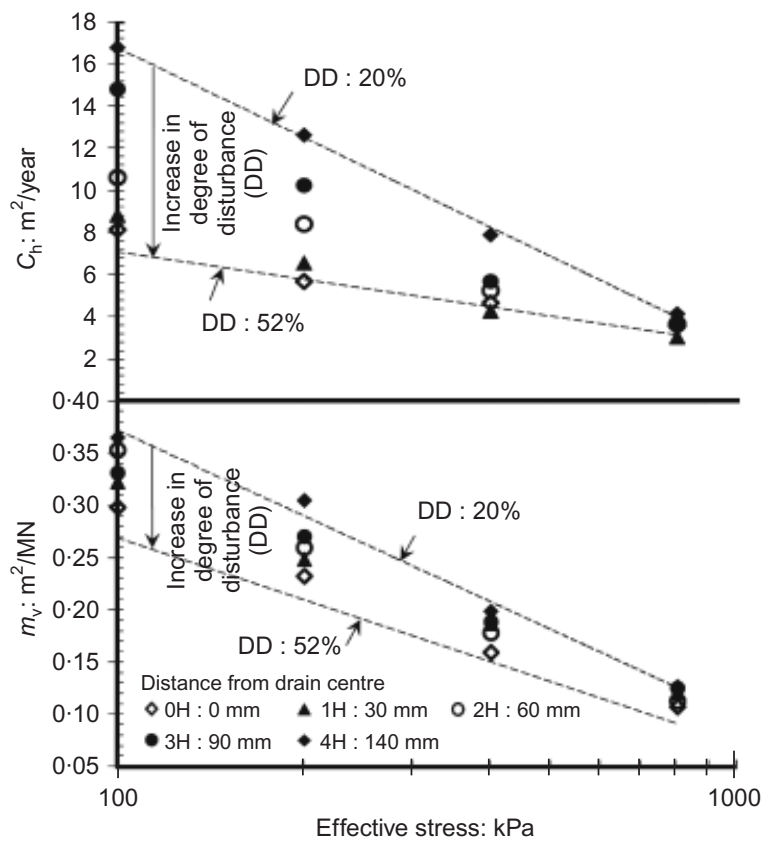

Fig. 10. Coefficient of consolidation $\left(C_{\mathrm{h}}\right)$ and coefficient of volume change $\left(m_{\mathrm{v}}\right)$ against effective stress

(c) Case $C$ (one-zone simulation). The unit cell consists of only one undisturbed zone (no smear zone). The third part of Table 4 tabulates the soil parameters used for Case C.

Totals of 455 elements, 470 elements and 498 elements were used in the finite-element analyses for the three-zone, twozone and one-zone simulations respectively. Fig. 12 shows the plots of the vertical displacement against time for the measured and predicted results. The pore pressure simulation at the bottom of the unit cell with $r=172.5 \mathrm{~mm}$ (Fig. 12(a)) shows that the time required for the excess pore pressure to

two zones that represent the smear zone and undisturbed zone. The soil properties based on the undisturbed sample (except for the permeability in the smear zone) are employed for all zones. The second part of Table 4 tabulates the soil parameters used for Case B.

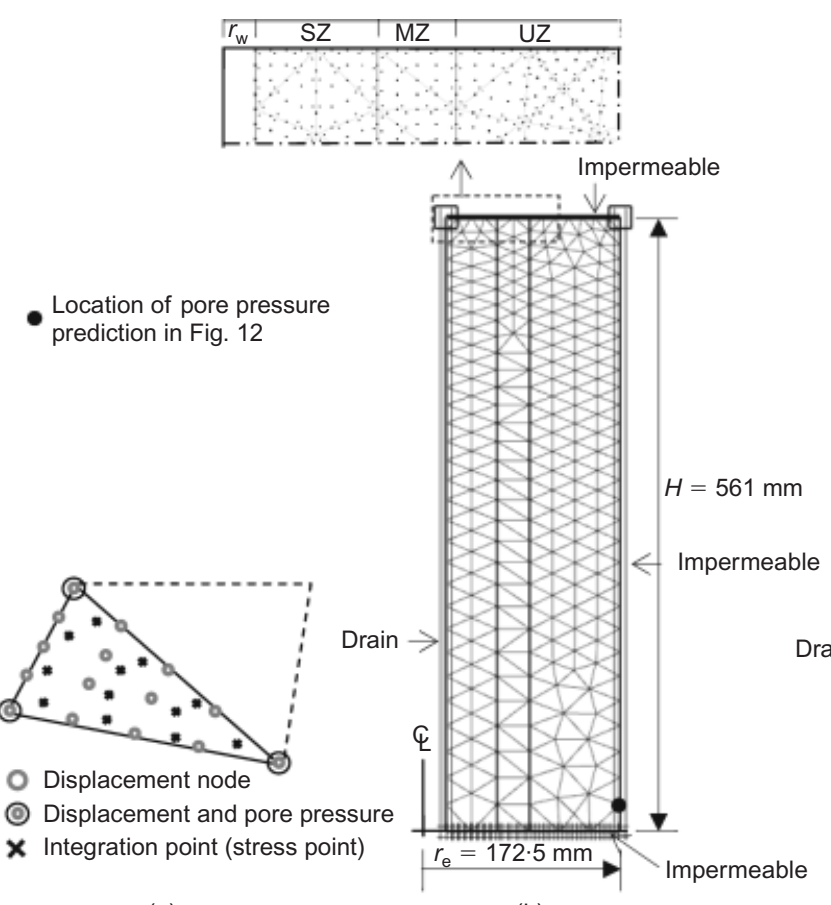

(a)
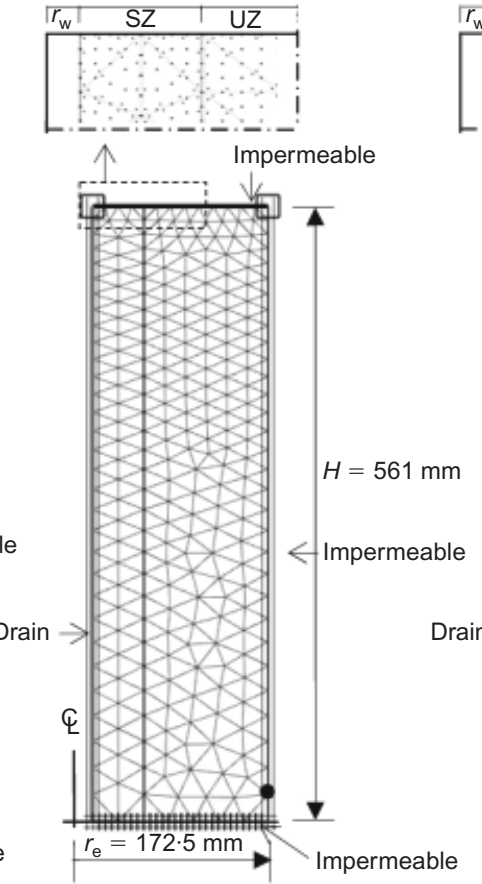

(c)

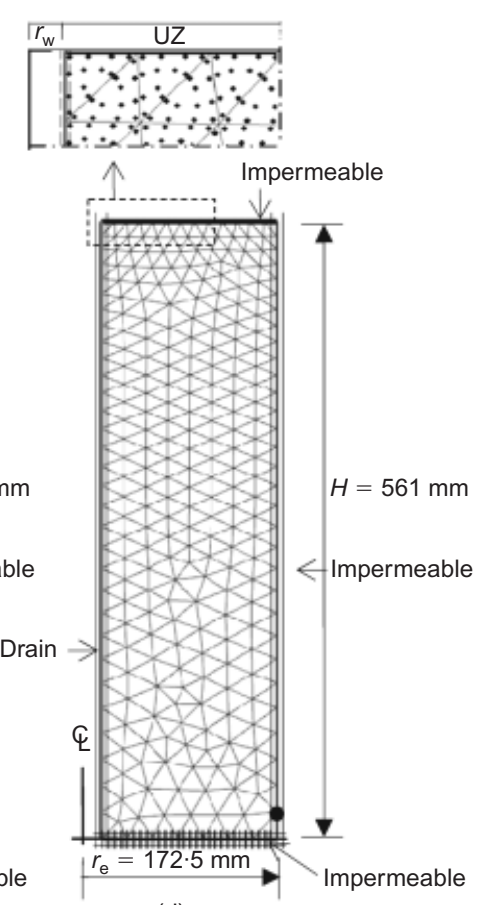

(d)

Fig. 11. (a) Nodes (displacements) and integration points (stress points) for single 15-node triangular element. Finite-element mesh for axisymmetric analysis of soil unit cell: (b) Case A; (c) Case B; (d) Case C (SZ, smear zone; MZ, marginally disturbed zone; UZ, undisturbed zone) 
Table 4. Soil parameters used in numerical analysis

\begin{tabular}{|c|c|c|c|c|c|c|c|}
\hline & \multicolumn{7}{|c|}{ Parameter } \\
\hline & $e_{0}$ & $\gamma: \mathrm{kN} / \mathrm{m}^{3}$ & $C_{\mathrm{c}}$ & $C_{\mathrm{s}}$ & $k_{\mathrm{h}} \times 10^{-9}: \mathrm{m} / \mathrm{s}$ & $k_{\mathrm{v}} \times 10^{-9}: \mathrm{m} / \mathrm{s}$ & $\sigma_{\text {yi }}^{\prime}: \mathrm{kPa}$ \\
\hline \multicolumn{8}{|l|}{ Case A } \\
\hline $\begin{array}{l}\text { Smear zone } \\
\text { Marginally disturbed zone } \\
\text { Undisturbed zone }\end{array}$ & $\begin{array}{l}0 \cdot 903 \\
1 \cdot 048 \\
1 \cdot 134\end{array}$ & $\begin{array}{l}18 \cdot 5 \\
18 \cdot 5 \\
18 \cdot 5\end{array}$ & $\begin{array}{l}0 \cdot 18 \\
0 \cdot 20 \\
0 \cdot 23\end{array}$ & $\begin{array}{l}0 \cdot 04 \\
0 \cdot 04 \\
0 \cdot 04\end{array}$ & $\begin{array}{l}0 \cdot 97 \\
2 \cdot 27 \\
3 \cdot 09\end{array}$ & $\begin{array}{l}0 \cdot 97 \\
1 \cdot 45 \\
2 \cdot 21\end{array}$ & $\begin{array}{l}100 \cdot 0 \\
125 \cdot 0 \\
130 \cdot 0\end{array}$ \\
\hline \multicolumn{8}{|l|}{ Case B } \\
\hline $\begin{array}{l}\text { Smear zone } \\
\text { Undisturbed zone }\end{array}$ & $\begin{array}{l}1 \cdot 134 \\
1 \cdot 134\end{array}$ & $\begin{array}{l}18 \cdot 5 \\
18 \cdot 5\end{array}$ & $\begin{array}{l}0 \cdot 23 \\
0 \cdot 23\end{array}$ & $\begin{array}{l}0 \cdot 04 \\
0 \cdot 04\end{array}$ & $\begin{array}{l}0.97 \\
3 \cdot 09\end{array}$ & $\begin{array}{l}0 \cdot 97 \\
2 \cdot 21\end{array}$ & $\begin{array}{l}130 \cdot 0 \\
130 \cdot 0\end{array}$ \\
\hline \multicolumn{8}{|l|}{ Case C } \\
\hline Undisturbed zone & $1 \cdot 134$ & $18 \cdot 5$ & $0 \cdot 23$ & $0 \cdot 04$ & $3 \cdot 09$ & $2 \cdot 21$ & $130 \cdot 0$ \\
\hline
\end{tabular}

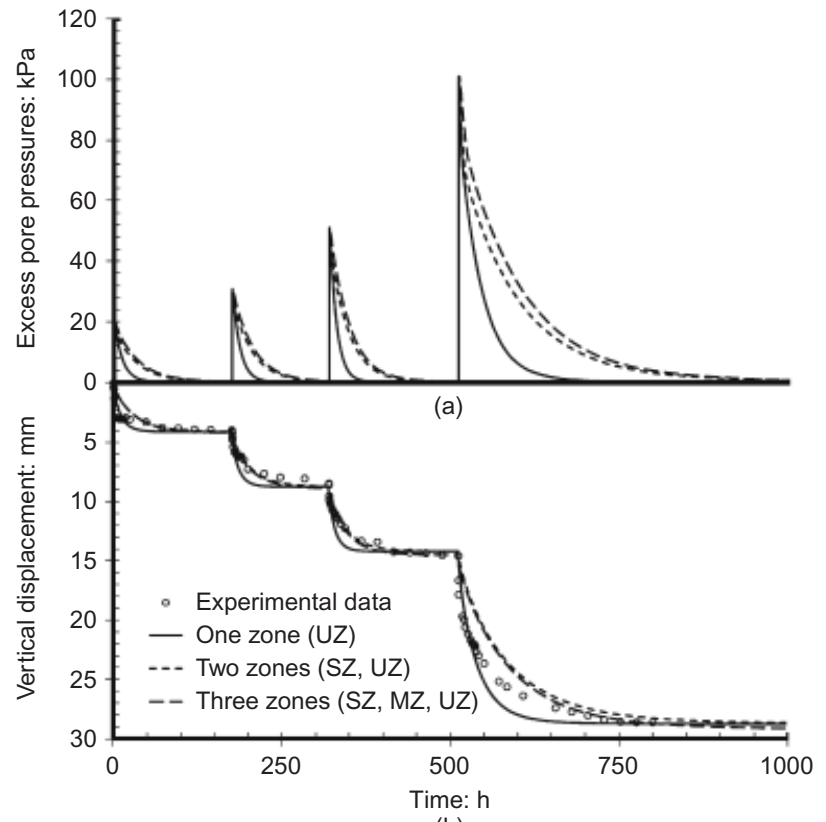

(b)

Fig. 12. (a) Excess pore pressure predictions based on finite-element analyses at bottom of unit cell with $r=172.5 \mathrm{~mm}$; (b) comparison of vertical displacements between laboratory measurements and finite-element predictions

dissipate in Case B is faster than that in Case A. This is because of the inclusion of marginally disturbed zone in Case B. For Case C, where the smear zone is not considered, the consolidation is, as expected, faster than those in the two previous cases. Meanwhile, for the settlement simulation (Fig. 12(b)), the inclusion of the marginally disturbed zone and the variation of soil compressibility due to the degree of disturbance in Case A are able to predict the time-dependent settlement better than in Cases B and C. Fig. 13 presents the contours of excess pore water pressure for all cases at time $=550 \mathrm{~h}$ and $600 \mathrm{~h}$. The difference between Cases A, B and $\mathrm{C}$ is marginal, because of the specimen size tested in the laboratory. From the results of the finite-element analysis, it is clear that the role of the MZ and soil structure in a unit cell analysis provides a more realistic prediction of consolidation.

\section{Practical implications and future research directions}

The economical design of preloading with PVDs depends critically on accurate assessment of the in situ values of soil permeability and compressibility. Numerous radial consolidation theories (Barron, 1948; Hansbo, 1981) have been proposed in the past to take account of the change in permeability within the smear zone, whereas the soil compressibility is usually kept constant in most studies for both the smear and undisturbed zones. However, during the installation of PVDs, both the in situ soil permeability and compressibility change substantially in the near vicinity of the drain, in comparison with the data obtained for the remoulded samples. These variables significantly affect the rate of settlement and excess pore pressure dissipation. From laboratory testing, it is clear that the size of the specimen plays a vital role in studying the effect of soil disturbance caused by PVD installation. To obtain more realistic results, it is suggested that a field trial with PVD installation be conducted to monitor both the settlement and the excess pore water pressure, and the authors of this paper have now planned this trial at the site of the Ballina Bypass under the auspices of a new Australian Research Council project. It is perceived that an assessment of these parameters would be based on undisturbed samples obtained at different distances from the vertical drains at the trial site. For the numerical analysis, the unit cell analysis should be extended to analyse the entire embankment where numerous vertical drains are installed under both two-dimensional and three-dimensional conditions.

\section{CONCLUSIONS}

These tests were carried out on a large $(300 \mathrm{~mm}$ diameter), undisturbed sample of Bulli clay, New South Wales, Australia, using a specially designed large-scale consolidometer. Two large specimens were consolidated with pressures of $50 \mathrm{kPa}$ and $200 \mathrm{kPa}$ prior to tests conducted on small cored samples in a conventional oedometer. Data from the tests were analysed to establish the characteristics of the smear zones and prediction of disturbance due to the soil being destructured in the smear zone. The extent of the smear zone was estimated on the basis of the normalised permeability $\left(k_{\mathrm{h}} / k_{\mathrm{hu}}\right)$ and the change in the water content. The smear zone and the marginally disturbed zone were found to be about 3.7 times and 5.5 times the equivalent radius of the mandrel respectively. The $50-80 \%$ drop of 


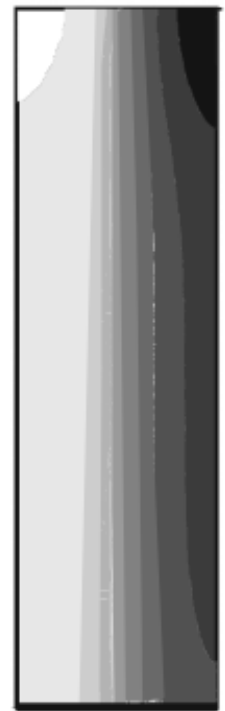

(a)

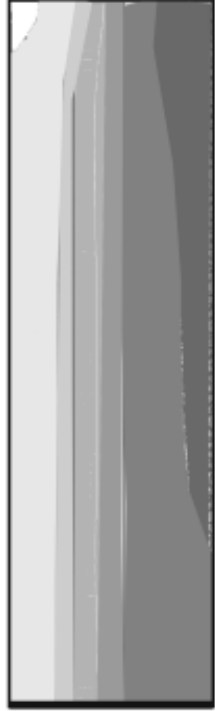

(b)

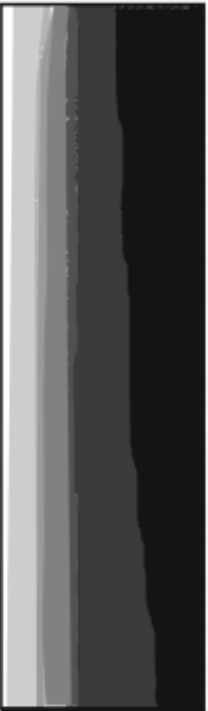

(c)

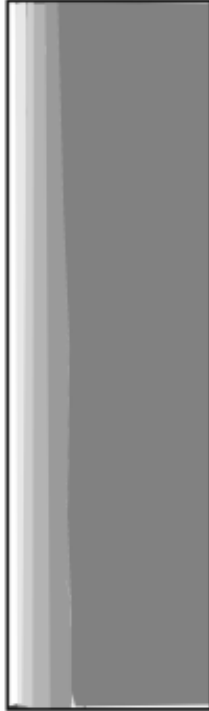

(d)

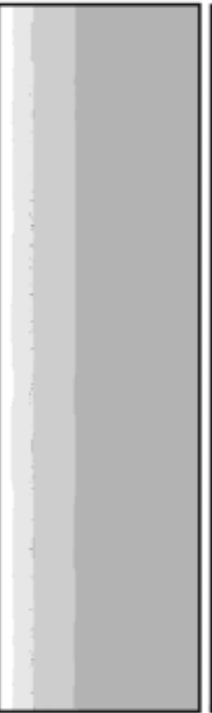

(e)

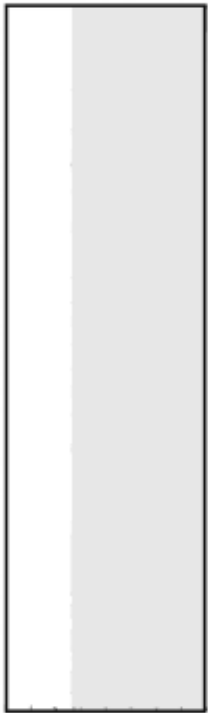

(f)
Excess pore

pressure: $\mathrm{kPa}$

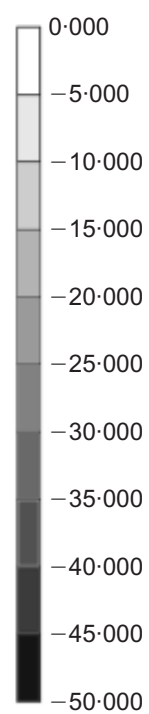

$-50 \cdot 000$

Fig. 13. Excess pore pressure contours of Series B: (a) Case A at time $=550 \mathrm{~h}$; (b) Case A at time $=600 \mathrm{~h}$; (c) Case B at time $=550 \mathrm{~h}$; (d) Case B at time $=600 \mathrm{~h}$; (e) Case C at time $=550 \mathrm{~h}$; (f) Case C at time $=600 \mathrm{~h}$

normalised permeability in the disturbed zone was significant, in that it was a larger drop in value than in similar works, which resulted in lower values of $32-40 \%$ when remoulded soil was used. The degree of soil disturbance in the disturbed zone was approximately $20-32 \%$ higher than that in the undisturbed zone. It was clear that the soil lost a significant amount of its structure after the drain was installed, especially in the region close to the drain.

The finite-element analyses show that inclusion of the marginally disturbed zone in a unit cell and variation of the coefficient compressibility due to the degree of disturbance provide a more realistic prediction of consolidation. When the soil is disturbed, the permeability, the coefficient of consolidation and the compression characteristics (including compressibility and preconsolidation pressure) are adversely affected. Therefore, based on these findings, the variation of soil properties due to drain installation needs to be taken into account during design, as well as the variation of soil permeability.

The economical design of preloading with PVDs depends critically on an accurate assessment of the in situ value of the soil permeability and compressibility. Numerous radial consolidation theories have been proposed in the past to take account of the change in permeability in the smear zone, whereas the soil compressibility is kept constant for both the smear and undisturbed zones. However, during the installation of PVDs, both the in situ soil permeability and the compressibility change substantially in the vicinity of the drain, in comparison with those obtained from remoulded samples. These variables significantly affect the rate of settlement and excess pore pressure dissipation. It is suggested that an assessment of these parameters be based on undisturbed samples obtained at different distances from the vertical drains.

\section{ACKNOWLEDGEMENTS}

The authors acknowledge the financial support provided by the Director General of Higher Education, Ministry of Education and Culture, Government of the Republic of Indonesia, and support from the Centre for Geomechanics and Railway Engineering, University of Wollongong, NSW, Australia.

\section{NOTATION}

$b$ parameter representing the rate of destructuring

$C_{\mathrm{a}}$ area ratio

$C_{\mathrm{c}}$ gradient of compression line of reconstituted soil in $e-\log \sigma_{\mathrm{v}}^{\prime}$ plot

$C_{\mathrm{h}}$ horizontal coefficient of consolidation

$C_{\mathrm{i}}$ inside clearance ratio

$C_{\mathrm{s}}$ gradient of recompression line of reconstituted soil in $e^{-} \log \sigma_{\mathrm{v}}^{\prime}$ plot

$C_{\mathrm{o}}$ outside clearance ratio

$D_{\mathrm{e}}$ inside diameter of cutting edge of sampling device

$D_{\mathrm{s}}$ inside diameter of sampling tube above cutting edge

$D_{\mathrm{t}}$ outside diameter of sampling tube

$D_{\mathrm{w}}$ outside diameter of tube that enters soil during sampling

DD degree of disturbance

$e^{*} \quad$ void ratio of reconstituted soil during isotropic compression

$e_{\mathrm{D}}$ void ratio in virgin yielding behaviour region

$e_{\mathrm{ic}}^{*} \quad$ void ratio of reconstituted soil when $p^{\prime}=1 \mathrm{kPa}$ during virgin isotropic compression

$e_{\text {id }}$ initial void ratio of partially disturbed soil

$e_{\text {id(ICL) }}$ void ratio on ICL at effective stress of $\sigma_{\mathrm{vy}, \mathrm{i}}^{\prime}$ in structured soil

$e_{\mathrm{P}} \quad$ void ratio of partially disturbed soil at yield points line

$e_{\mathrm{sc}}$ void ratio of undisturbed (structured) soil

$e_{\mathrm{SD}}$ void ratio of partially disturbed soil in elastic behaviour region

$e_{0} \quad$ initial void ratio

$\Delta e_{\mathrm{i}} \quad$ difference in void ratio between structured and reconstituted soil at initial yield point

$k_{\mathrm{h}}$ horizontal permeability of partially undisturbed soil

$k_{\text {hu }}$ horizontal permeability of undisturbed soil

$k_{\mathrm{v}} \quad$ vertical permeability of soil

$m_{\mathrm{v}}$ coefficient of volume change

$p^{\prime}$ current mean effective stress

$p_{\mathrm{s}}^{\prime} \quad$ value of current structural yield surface of partially disturbed soil

$p_{\mathrm{y}, \mathrm{i}}^{\prime} \quad$ value of mean effective stress at initial yield point

$r_{\mathrm{md}}$ marginally disturbed zone

$r_{\mathrm{m}, \mathrm{eq}}$ equivalent radius of mandrel

$r_{\mathrm{s}}$ smear zone radius

$r_{\mathrm{W}}$ equivalent drain radius

$\gamma$ bulk unit weight of soil

$\kappa$ gradient of isotropic recompression line of reconstituted soil in $e-\ln p^{\prime}$ plot

$\lambda^{*}$ gradient of ICL of reconstituted soil in $e-\ln p^{\prime}$ plot

$\sigma_{\mathrm{v}}^{\prime} \quad$ vertical effective stress

$\sigma_{\mathrm{vs}}^{\prime} \quad$ current structural yield stress of partially disturbed soil 
$\sigma_{\mathrm{vy}, \mathrm{i}}^{\prime}$ initial yield stress of structured soil $(\mathrm{kPa})$

$\sigma_{\mathrm{vy}, \mathrm{iD}}^{\prime}$ initial yield stress of the partially disturbed soil $(\mathrm{kPa})$

\section{REFERENCES}

Barron, R. A. (1948). Consolidation of fine-grained soils by drain wells. Trans. ASCE 113, No. 2346, 718-742.

Bergado, D. T., Asakami, H., Alfaro, M. \& Balasubramaniam, A. (1991). Smear effects of vertical drains on soft Bangkok clay. J. Geotech. Engng 117, No. 10, 1509-1530.

Bo, M., Chu, J., Low, B. K. \& Choa, V. (2003). Soil improvement: Prefabricated vertical drain techniques. Singapore: Thomson Learning.

Burland, J. B. (1990). On the compressibility and shear strength of natural soils. Géotechnique 40, No. 3, 329-378, http://dx.doi. org/10.1680/geot.1990.40.3.329.

Brinkgreve, R. B. J., Swolfs, W. M. \& Engin, E. (2011). PLAXIS 2D 2011. Delft, the Netherlands: Plaxis BV.

Chai, J.-C. \& Miura, N. (1999). Investigation of factors affecting vertical drain behavior. J. Geotech. Geoenviron. Engng, ASCE 125, No. 3, 216-226.

Chu, J., Yan, S. \& Yang, H. (2000). Soil improvement by vacuum preloading method for an oil storage station. Géotechnique $\mathbf{5 0}$, No. 6, 625-632, http://dx.doi.org/10.1680/geot.2000.50.6.625.

Coop, M. R., Atkinson, J. H. \& Taylor, R. N. (1995). Strength, yielding and stiffness of structured and unstructured soils. Proceedings of the 11th European Conference on Soil Mechanics and Foundation Engineering, Copenhagen, pp. 55-62.

Cuccovillo, T. \& Coop, M. R. (1999). On the mechanics of structured sands. Géotechnique 49, No. 6, 741-760, http:// dx.doi.org/10.1680/geot.1999.49.6.741.

Gens, A. \& Nova, R. (1993). Conceptual bases for a constitutive model for bonded soils and weak rocks. In Geotechnical engineering of hard soils-soft rocks (eds A. Anagnostopoulos, F. Schlosser, N. Kalteziotis and R. Frank), vol. 1, pp. 485-494. Rotterdam, the Netherlands: A. A. Balkema.

Ghandeharioon, A., Indraratna, B. \& Rujikiatkamjorn, C. (2010). Analysis of soil disturbance associated with mandrel-driven prefabricated vertical drains using an elliptical cavity expansion theory. Int. J. Geomech., ASCE 10, No. 2, 53-64.

Hansbo, S. (1981). Consolidation of fine-grained soils by prefabricated drains. Proceedings of the 10th International Conference on Soil Mechanics and Foundation Engineering, Stockholm, pp. 677-682.

Hight, D. \& Leroueil, S. (2003). Characterisation of soils for engineering purposes. Proceedings of the workshop on characterisation and engineering properties of natural soils, Singapore, pp. 255-360.

Hird, C. \& Moseley, V. J. (2000). Model study of seepage in smear zones around vertical drains in layered soil. Géotechnique 50, No. 1, 89-97, http://dx.doi.org/10.1680/geot.2000.50.1.89.

Hvorslev, M. J. (1949). Subsurface exploration and sampling of soils for civil engineering purposes. Vicksburg, MS, USA: US Army Engineer Waterways Experiment Station.

Indraratna, B. \& Redana, I. W. (1998). Laboratory determination of smear zone due to vertical drain installation. J. Geotech. Geoenviron. Engng 124, No. 2, 180-184.

Indraratna, B. \& Redana, I. W. (2000). Numerical modeling of vertical drains with smear and well resistance installed in soft clay. Can. Geotech. J. 37, No. 1, 1-14.
Kavvadas, M. \& Amorosi, A. (2000). A constitutive model for structured soils. Géotechnique 50, No. 3, 263-273, http:// dx.doi.org/10.1680/geot.2000.50.3.263.

Leroueil, S. \& Vaughan, P. (1990). General and congruent effects of structure in natural soils and weak rocks. Géotechnique 40, No. 3, 467-488, http://dx.doi.org/10.1680/geot.1990.40.3.467.

Leroueil, S., Tavenas, F., Brucy, F., La Rochelle, P. \& Roy, M. (1979). Behaviour of destructured natural clays. J. Geotech. Engng Div., ASCE 105, No. 6, 759-778.

Liu, M. D. \& Carter, J. P. (1999). Virgin compression of structured soil. Géotechnique 49, No. 1, 43-57, http://dx.doi.org/10.1680/ geot.1999.49.1.43.

Liu, M. D. \& Carter, J. P. (2000). Modelling the destructuring of soils during virgin compression. Géotechnique 50, No. 4, 479483, http://dx.doi.org/10.1680/geot.2000.50.4.479.

Liu, M. D. \& Carter, J. P. (2002). A structured Cam Clay model. Can. Geotech. J. 39, No. 6, 1313-1332.

Madhav, M. R., Park, Y. M. \& Miura, N. (1993). Modelling and study of smear zone around band shape drains. Soils Found. 33, No. 4, 135-147.

Nagaraj, T. S., Srinivasa Murthy, B. R., Vatsala, A. \& Joshi, R. C. (1990). Analysis of compressibility of sensitive clays. J. Geotech. Engng 116, No. 1, 105-118.

Nagendra Prasad, K., Triveni, S., Schanz, T. \& Late, T. S. (2007). Sample disturbance in soft and sensitive clays: analysis and assessment. Mar. Georesour. Geotechnol. 25, No. 3-4, 181-197.

Onoue, A., Ting, N. H., Germaine, J. T. \& Whitman, R. V. (1991). Permeability of disturbed zone around vertical drains. Proceedings of the ASCE geotechnical engineering congress, pp. 879890. Reston, VA, USA: ASCE.

Roscoe, K. H. \& Burland, J. B. (1968). On the generalised stress strain behaviour of 'wet clay'. In Engineering plasticity (eds J. Heyman and F. A. Leckie), pp. 535-609. Cambridge, UK: Cambridge University Press.

Rouainia, M. \& Muir Wood, D. (2000). A kinematic hardening model for natural clays with loss of structure. Géotechnique $\mathbf{5 0}$ No. 2, 153-164, http://dx.doi.org/10.1680/geot.2000.50.2.153.

Rowe, P. W. (1972). The relevance of soil fabric to site investigation. Géotechnique 22, No. 2, 195-200, http://dx.doi.org/ 10.1680/geot.1972.22.2.195.

Rutledge, P. C. (1944). Relation of undisturbed sampling to laboratory testing. Trans. ASCE 109, No. 1, 1155-1183.

Sathananthan, I. \& Indraratna, B. (2006). Laboratory evaluation of smear zone and correlation between permeability and moisture content. J. Geotech. Geoenviron. Engng 132, No. 7, 942-945.

Schmertmann, J. H. (1955). The undisturbed consolidation behaviour of clay. Trans. ASCE 120, 1201-1233.

Sharma, J. S. \& Xiao, D. (2000). Characterization of a smear zone around vertical drains by large-scale laboratory tests. Can. Geotech. J. 37, No. 6, 1265-1271.

Skempton, A. W. (1985). Residual strength of clays in landslides, folded strata and the laboratory. Géotechnique 35, No. 1, 1-18, http://dx.doi.org/10.1680/geot.1985.35.1.1.

Wheeler, S. J. (1997). A rotational hardening elasto-plastic model for clays. Proceedings of the 14th international conference on soil mechanics and foundation engineering, Hamburg, vol. 1, pp. $431-434$.

Whittle, A. J. (1993). Evaluation of a constitutive model for overconsolidated clays. Géotechnique 43, No. 2, 289-314, http:// dx.doi.org/10.1680/geot.1993.43.2.289. 